\title{
Feminizáció és szakmásodás a dualizmus-kori pedagógiai folyóiratok tükrében
}

\author{
NóBiK Attila \\ SZTE JGYPK
}

\begin{abstract}
Ma Magyarországon, ahogy a világ oktatási rendszeriben általában, a nők vannak többségben a pedagóguspályán. Miközben a nemzetközi szakirodalomban a feminizáció jelenségének történetére és következményeire vonatkozóan számos kutatás zajlott, hazánkban a téma kevéssé kutatott. Ezért e tanulmány a néptanítói szakma feminizációja kezdeteinek feltárására tesz kísérletet, forrásként dualizmus-kori pedagógiai folyóiratokat használva. A tanulmány első részében a téma elméleti és nemzetközi kontextusát, majd a néptanítói szakma feminizációjának hazai kezdeteit mutatjuk be. A vizsgált forrásainkból kiderül, hogy a tanítónők számarányuknál kisebb súllyal tudtak részt venni a pedagógiai közéletben. A jelenség megértéséhez a hatalom fogalmának értelmezéseiben találhatunk segítséget.
\end{abstract}

Kulcsszavak: feminizáció, pedagógiai sajtó, dualizmus

Az utóbbi évtizedben a nőnevelés történetével foglalkozó kutatások megélénkülése figyelhető meg a magyar neveléstörténeti kutatásokban. Találhatunk a nőnevelés történetét általánosan, nemzetközi kontextusban tárgyaló munkát (Pukánszky, 2006) éppúgy, mint olyat, amelyik elsősorban a 19. században megváltozó női szerepekre fókuszál (Kéri, 2008). Vannak kutatások, amelyek a nők és az oktatásügy kapcsolatának egy szeletét vizsgálják. Hegedús Judit tanítónői karriertörténeteket elemzett (Hegedüs, 20003), Sztrinkóné Nagy Irén (2005) a nők szerepét vizsgálta a magyar reformpedagógiai mozgalmakban, míg Bíró Zsuzsanna Hanna (2014) a női bölcsészdiplomások társadalmi helyzetének elemzését végezte el a történeti oktatásszociológia eszközeivel.

Miközben a fent vázlatosan említett kutatások számos esetben alapvető tényeket hoztak felszínre, egyelőre kevésbé hangsúlyosan vannak jelen azok a vizsgálatok (pl. Kereszty, 2011b), amely a téma társadalmi nemek elmélete felőli megközelítésére, vizsgálatára vállakoznak. Ahogy Thun Éva megjegyezte: „A nőneveléstörténeti interpretálások sajnálatos módon nem kísérlik meg a nők oktatása intézményesülésének politikai ételemben vett jelentöségét elhelyezni az adott korok társadalmi kontextusaiban" (Thun, 2012. 367. o.). 
Noha a megfogalmazott kritika talán túl szigorú, valóban sajátossága a magyar nőnevelés-történeti kutatásoknak, hogy ezek elsősorban az oktatástörténeti folyamatokra fókuszáltak. A szakmásodás témakörében például foglalkoztak azzal, hogyan jelentek meg a nők a tanítónői pályán (pl. Nagy, 2001, 2006), az ugyanakkor eddig feltáratlan maradt, hogy a tanítónők bekapcsolódtak-e, és ha igen, milyen módon a szakmai közéletbe. Ezért a kutatás ezen részének célja a néptanítói szakmásodás „női oldalának”, a néptanító szakma feminizációja következményeinek feltárása volt.

\section{A NÉPTANÍTÓI SZAKMA FEMINIZÁCIÓJA NEMZETKÖZI KONTEXTUSBAN}

A nemzetközi szakirodalomban (pl. Cortina és San Román, 2006) jelentôs érdeklődés mutatkozott a tanítói szakma feminizációja iránt. A feminizáció a nemzetközi szakirodalomban széleskörúen elterjedt fogalom. Ha az oktatás feminizációjára utal, akkor az a "nőknek a pedagóguspályán történő nagy létszámú megjelenését" írja le (Wylie, 2000. 1. o. idézi: Kelleher, 2011. 1. o.). A magyar szakirodalom erre a jelenségre hagyományosan az elnőiesedés kifejezést használja. Jelen kutatásban azonban ennek a kifejezésnek a mellőzése mellett döntöttem, elsősorban a hozzá tapadó negatív konnotációk (leértékelődés, csökkenő presztízs) miatt.

A feminizációnak három jelentése különböztethető meg: „a) egy statisztikai jelentés, amit a nők és a férfiak arányának kiszámítására használnak egy szakmában; b) a számok súlyának hatásával kapcsolatos jelentés; és c) a nők hivatáshoz való hozzáférésnek aránya" (Kelleher, 2011 1. o.).

A témával foglalkozó kutatásokban gyakran megjelenik (ha nem is expliciten kifejezve) az a feltételezés, hogy a feminizáció alapvetően felzárkózási folyamat, amelynek során a női pedagógusok professzionalizmusának szintje közelített a férfi pedagógusokéhoz. Ezért a Kelleher által említett két utolsó aspektust gyakran nem vizsgálják. Pedig kutatásuk elengedhetetlenen lenne a feminizációt meghatározó mögöttes folyamatok megértéséhez. Ennek igazolására utalhatunk Strober és Lanford mára már klasszikussá vált tanulmányára, amelyben rávilágítottak a feminizáció néhány fontos következményére: „a nemi szegregáció legalább két káros hatással jár. Először is meggátolja a férfiakat és a nőket abban, hogy olyan hivatást válasszanak, amelyek megfelelnek a tehetségüknek és készségeiknek, és ösztönzi őket arra, hogy a társadalmi sztereotípiáknak megfelelően válasszanak. Az ilyen korlátozott választások csökkentik az egyéni megelégedettséget és a potenciális gazdasági teljesítményt. Másodszor, a foglalkozási szegregáció felelő a férfiak és a nők közötti bérés fizetéskülönbség nagy részéért" (Strober és Lanford, 1986. 213. o.).

A nemzetközi történeti kutatások számos régióban feltárták a feminizáció jellemzőit. Trouvé-Finding azt vizsgálta, hogy a nők nagy mértékú pályára lépésének milyen hatásai voltak Angliában és Franciaországban a késő 19. és kora 20. században (Trouvé-Finding, 2005). Clifford pedig a női pedagógusok 
20 század végéig tartó társadalomtörténetét írta meg az Egyesült Államokat kutatva (Clifford, 2014).

Kanadával számos tanulmány foglalkozott. A kanadai tanítónők 1881 és 1901 közötti helyzetét tekintette át Sager (2007) tanulmányában, építve például Janet Guilford jelentős, Nova Scotiát vizsgáló kutatására (Guilford, 1992). Sager felhívja a figyelmet arra, hogy a nők karrierválasztásában jelentősen összefonódnak a terülteti minták az egyéni motivációkkal. „A nők úgy döntöttek, hogy pedagógusi pályára lépnek, és ezt akkor tették, amikor szembesültek a korlátozott, de változó lehetóségekkel azon közösségekben, ahol éltek. Az elhatározást, hogy pedagógusokká válnak vagy azok maradnak akkor hozták meg, amikor a személyes vágyak és a családi igények találkoztak egyes speciális munkakörökkel és feltételekkel, mint az elérhetö pedagógusi álláshelyek száma; az, hogy ezeken a munkakörökben mennyi volt a férfi versenytársak száma és elérhetösége; valamint az, hogy milyen mértékben vált kulturálisan elfogadottá a nők részvétele a háztartáson kívüli fizetett munkaeröpiacon" (Sager, 2007. 235-236.).

Narcisio de Gabriel a nők pedagóguspályára lépését vizsgálta Spanyolországban. Szoros kapcsolatot talált a feminizmus és a feminizáció között, ugyanakkor az eredményei meglepőnek hatottak. "A nők fokozatos bevonódása a pedagógusi hivatásba közvetlenül kapcsolódik a feminista követelésekhez. A feminizmus követelte az oktatáshoz és a nők fizetett munkához való jogát, és éppen a lányok oktatása tette lehetövé a nők számára, hogy gyakorolhassák azokat az első foglalkozásokat, amikhez hozzáférhettek. A nöi pedagógus alakja is patriarchális elgondolásokra épült, mégis éroként jelent meg egy olyan teljesítmény eléréséhez, amely magának a patriarchális rendszer néhány alapját kérdöjelezte meg. Paradox módon, a függésre nevelés, amelyet a lányok kaptak az iskolában, segítette a nőket egy olyan szakmához való hozzáférésben, amely autonómiát biztosított számukra" (de Gabriel, 2014. 353-354. o.).

A tanítónők arányának növekedése tehát mindenhol megfigyelhető a modern népoktatási rendszerekben. Nagy hatású összehasonlító tanulmányában Albisetti (1993) megállapítja, hogy sem földrajzi, sem vallási, sem iparosodottsági szempontok alapján nem lehet egyértelmú mintákat találni.

A gyorsan fejlődo és iparosodó, nagyobbrészt protestáns Németországban 1911-ben „csupán” 20,9\% volt a tanítónők aránya. A skandináv államok közül Dánia mutat hasonló arányt a 1895-ös 28\%-kal. Svédországban ugyanakkor a századfordulón a tanítók $66 \%$-a volt nő. Norvégia a két érték közé esett 34\%-kal.

A katolikus országok között sem beszélhetünk egységes mintákról. Franciaországban 1906-ban 46\% volt a tanítónők aránya, ami közel állt a szomszédos Belgium adataihoz, ahol az 1848-ban megfigyelhető 40\%-ról 1896-ra 49\%-ra kúszott fel az arány. A katolikus Portugáliában szintén ezekhez közeli értéket, 49\%-ot találunk a századfordulón. Ausztriában ugyanakkor a tanítóknak csupán 29\%-a volt nő (sokuk képesítetlen), miközben Olaszországban 68\%-a. Ez utóbbi adat közelebb áll az egymástól kulturálisan messze álló Oroszországhoz (kb. 70-75\%), Angliához (73\% a századfordulón), az Egyesült Államokhoz (75\% a századfordulón) vagy éppen Kanadához (65\% - 1880; 80\% - 1905).

Egyértelmú minták tehát nem azonosíthatók, Albisetti (1993) ugyanakkor 
kiemel három faktort, amelyek jelentős hatást gyakorolhattak a feminizáció mértékére: a képzés szigorúsága, a házas tanítónőkkel szembeni tiltások és a városiasodottság. Az elemzésekből úgy tûnik, hogy minél hosszabb, formalizáltabb és szigorúbban szabályozott volt a képzés (pl. Németországban), annál inkább hátráltatta a nők pályára lépését. Bár kevés ország alkalmazott explicit tiltásokat a férjezett tanítónők alkalmazásával szemben, az ő ritkább alkalmazásuk elterjedt gyakorlat volt. Végül kijelenthető, hogy a városokban mindenhol magasabb volt a nők aránya a pályán, mint vidéken. Ez, mint látni fogjuk, Magyarországon is igaz volt.

A helyzet kuszasága miatt Albisetti óvatosságot javasol az elemzésekben. "A feminizáció szintjét befolyásoló tényezók nagy száma, beleértve a gazdasági feltételeket, a jogot, a vallást, a kulturális hagyományokat, a társadalmi nemi ideológiákat, az iskolázottsági hosszát, az urbanizációt és a háborúkat, szembe megy bármilyen egyszerü magyarázattal" (Albisetti, 1993. 213. o.).

A fenti rövid áttekintésből is látszik, hogy noha még számos feltáratlan terület van a feminizációval kapcsolatban, annyi bizonyosan kijelenthető, hogy az a professzionalizáció mellett a modern oktatási rendszerek másik jelentős kulcsfolyamata.

\section{A NÉPTANÍTói SZAKMA FEMINIZÁCIÓJA MAGYARORSZÁGON}

Ahogy korábban is láttuk, a professzionalizáció-kutatások részeként számos kutatás foglalkozott az elmúlt évtizedben magyar néptanítói szakma (ki)alakulásával. A tanítónőkkel kapcsolatos kutatások száma alacsony, és elsősorban a szakmában való megjelenésükre koncentrál.

A tanítónők száma a dualizmus időszakában dinamikusan növekedett. 1890ben az összes néptanító (23.382 fő) 12\%-a nő volt. Ez az arány 1900-ra 20\%-ra nőtt, a törvényhatósági jogú városokban pedig 45\%-ra (Nagy, 2001. 16. o.). Ezek a számok alacsonyabbak, mint Ausztriában, és hasonlóak, mint Németországban.

Komáromy Lajos áttekintve a népoktatás 1888-89-es helyzetét a következőket írta: „A tanítónők alkalmazásának erős növekedését mutatja az is, hogy az ujonnan rendszeresített 266 tanitói állomásból a nötanitó 57,51\% arányt foglaltak el, míg a férfitanitók csak 42,49\% arányt. Legujabban már nemcsak az állami és községi iskolák, hanem a római katholikus felekezetiek is jelentékeny számban alkalmaztak nőtanitókat. Az állami iskolákban a tanitóknak 37\%-a volt nőtanitó, a községi és római katholikus iskolákban 22-22\%, az izraelita iskolában 12\%, a magán iskolákban 55\%, az egyesületiekben 61\%." (Komáromy, 1890 77.o.).

A tanítónőképzők számának növekedése szintén dinamikus volt. Az első ilyen intézményt 1856-ben hozták létre az angolkisasszonyok (Hegedüs, 2003). 1868-ban 39 tanító- és tanítónőképző volt Magyarországon. Ez a szám 1918-ra 91 intézményre növekedett. A bővülés elsősorban a tanítónőképzők számának növekedéséből ered. 1868-ban számuk csupán 5 volt (mind katolikus), ez 1918-ra 
40-re növekedett (Kékes Szabó, 2003). Dinamikusan emelkedett a tanítónőképzőkbe járók száma is. „Míg 1868-ban 119 tanulója volt összesen 5 képzőnek, addig 1880-ban 1283 tanulót találunk összesen 16 tanitónőképzőben. Látható tehát, hogy az iskolák számának növekedése nem követi a létszám növekedését. Míg 1868-ban az egy iskolára jutóátlag 23,8 fó volt, addig ez a szám 1880-ban 80,2." (Neszt, 2010. 315. o.). A polgári iskolai tanítónők képzése pedig a Zirzen Janka által 1873-ban megszervezett, később Erzsébet Nőiskola néven ismert képzőben indult meg (Fizel, 2018. 74-75. o.)

A növekedés egyik oka az volt, hogy a népoktatási törvény nem tett különbséget a tanítók és tanítónők képzése között. A szabályozás szerint a képesítésüknek ugyanolyan értéke volt, és ugyanolyan esélyük volt az álláshelyek elnyerésére. A valóság természetesen ezt az egyenlőséget jellemzően felülírta. Az oktatási kormányzat a néptanítók „túltermelésétől” és munkanélküliségétől való félelemében kezdetben többször is megpróbálta korlátozni a tanítónők bejutását a képzésbe. Ezek a kísérletek azonban sikertelenek maradtak. A tanítónői munkanélküliségtől való félelem eltúlzottnak bizonyult. Részben azért, mert az iskolarendszer expanziója elegendő számú álláshelyet biztosított számukra, részben pedig azért, mert a tanítónőknek más „karrierlehetőségeik” is voltak. Általános társadalmi elvárás volt a tanítónőkkel szemben a házasság, bár a 19. század végén a tanítónőknek csupán $23 \%$-a volt házas, míg a férfi tanítók 73\%-a. Mivel ekkor a tanítónők 73\%-a 20 és 39 év közötti volt, és csupán 15\%-a 40 és 59 év közötti, óvatosan feltehetjük, hogy számos férjezett tanítónő elhagyta a pályát.

A házassági stratégiák szerepe a feminizációban ugyanakkor egyelőre nem feltárt. Habár a hivatalos szabályozás nem tett különbséget férjezett és egyedülálló tanítónők között, más források egyértelmúen arra utalnak, hogy a nemük és családi állapotuk befolyásolta a tanítónők alkalmazását. A felekezeti iskolák ellenállását részben az is indokolta, hogy a tanítói állások számos helyen olyan egyházi állásokkal (pl. kántor) voltak összekötve, amelyeket nő nem láthatott el.

A tanítói szakma feminizációja ugyanakkor több okból is feltartóztathatatlan volt. Egyik ilyen ok volt az, hogy - ahogy korábban említettem - az oktatási rendszer expanziója olyan mennyiségú álláshelyet hozott létre, amelyet lehetetlen volt férfiakkal feltölteni. Ezért miniszteri rendeletek kötelezték az állami és községi iskolákat tanítónők felvételére, különösen lányok és fiatal fiúk tanítására.

Másik ok volt a hagyományos középosztály társadalmi helyzetének változása. Számos középosztálybeli család elszegényedett, és férfi tagjai kénytelenek voltak hivatali állásokat vállalni. Lányaikat keresőképes foglalkozásra való felkészítéssel tudták támogatni. A társadalmi környezet és a polgári családok szerkezetének változása csak erősítette ezt a folyamatot, és a munkaerőpiacra lépésre kényszerítette a középosztálybeli lányokat, akik számára a tanítónői szakma ideálisnak bizonyult (Neszt, 2010). Mindez azt is eredményezte, hogy a tanítónők társadalmi háttere jellemzően magasabb volt, mint a férfi tanítóké. A magyar neveléstörténeti kutatásokban alig jelent meg a fenti folyamatok 
hatásának vizsgálata.

Jelen vizsgálat előzményeként említhető, hogy egy korábbi kutatásomban (Nóbik, 2014) azt igyekeztem feltárni, hogy a tanítónők bekapcsolódtak-e, és ha igen, milyen módon 1887 és 1891 között a Család és Iskola címú folyóiratban folyó szakmai diskurzusokba. A kutatás legfontosabb megállapítása azonban az volt, hogy a néptanítóság szakmai közéletére, a néptanítói tudáskánon formálóira a feltételezettnél is erősebb férfidominancia volt jellemző, a pályára lépő nők ekkor még nem tudták áttörni a szakma hagyományos hatalmi viszonyait a Család és Iskolában.

Ezért a jelen kutatásban a vizsgált időszakot megtartva, de a forrásbázist kibővítve vizsgáltam, hogy a tanítói pálya feminizálódásának következtében megjelennek-e a tanítónők a szakmai közéletben, és ha igen, akkor megfigyelhető-e a témák feminizálódása.

Kitekintésként érdemes megemlíteni, hogy míg a neveléstörténeti kutatásokban eddig kevéssé jelent meg a feminizáció kutatása, pszichológusok és oktatásszociológusok tettek kísérletet a feminizáció okozta kihívások, ideértve a férfi szerepmodellek és fegyelmi problémák feltérképezésére (N. Tóth, 2014).

Közülük néhányan megkérdőjelezték a feminizáció hagyományos értelmezését, és amellett érveltek, hogy a feminizáció nem okozója, hanem következménye a pedagógusszakmák leértékelődésének. Véleményük szerint a férfiak az alacsony jövedelmi viszonyok, a kihívást jelentő körülmények és a csökkenő presztízs miatt hagyták el a pályát. Ezeket az elhagyott pozíciókat foglalták el a nő, kihasználva az oktatási rendszer expanzióját (Fónai és Dusha, 2014).

Az oktatásszociológiai kutatások egy másik ígéretes aspektusa annak hangsúlyozása, hogy a feminizáció nem csupán a női pedagógusok számának növekedését, hanem a pályával szembeni elvárások átalakulását is jelenti. A feminizációval párhuzamosan olyan értékek (pl. gondoskodás, empátia) váltak meghatározóvá, amelyeket a társadalom tradicionálisan a női szerepekkel azonosít (Kovács, 2015). A tanári pályával kapcsolatos értékelvárások vizsgálata érdekes területe lehetne a neveléstörténeti kutatásoknak is.

A fenti elméleti háttérre és kutatási előzményekre alapozva kutatásomban a feminizáció hatásának egy kis szeletét vizsgáltam. Kutatásom célja annak feltárása volt, hogy a tanítónők arányának emelkedése magával hozta-e bekapcsolódásukat a pedagógiai közéletbe, képesek voltak-e érdemben befolyásolni a folyóiratok témáit, diskurzusait, és reflektáltak-e saját helyzetükre hazai és nemzetközi kontextusban.

A vizsgált folyóiratok a következők voltak: Néptanitók Lapja, Család és Iskola, Felső Nép- és Polgári Iskolai Közlöny, Kalauz a Népiskolai Nevelö-Oktatás Terén, Protestáns Egyházi és Iskolai Lapok, Evangélikus Egyház és Iskola valamint a Nemzeti Nőnevelés. A kiválasztott folyóiratok mind több évig megjelenő, népszerú folyóiratnak számítottak. Megtalálható közöttük hivatalos közlöny, regionális szakmai lap, katolikus és protestáns szakfolyóirat is. 


\section{NŐI SZERZŐK A FOLYÓIRATOKBAN}

A női szerzők aránya az összes folyóiratban nagyon alacsony volt. A három egyházi fenntartású folyóiratban egyáltalán nem találunk női szerzőt. A Néptanítók Lapja három évfolyamában $(1887,1888,1889)$ szintén nincs tanítónő a szerzők között. Vagyis a tanítónők növekvő arányáról tanúskodó adatok ellenére a vizsgált az egyházi és állami pedagógiai újságokban a tanítónők hangja nem jelent meg.

A másik végletet a Nemzeti Nőnevelés jelentette, ahol a női szerzők aránya minden vizsgált évben meghaladta a $20 \%$-ot, sőt 1891 -ben elérte a $40 \%$-ot is (42/17). A vizsgált folyóiratok közül ez az egyetlen, amelynek női szerkesztője volt. Sebestyén Gyuláné Stetina Ilona (1855-1932) 1890-től 1915-ig töltötte be a főszerkesztői posztot.

Stetina Ilona a dualizmus-kori nőnevelés kiemelkedő alakja volt. 1876-tól bekapcsolódott a Zirzen Janka vezette Állami Polgári Iskolai Tanítónőképzőintézet munkájába. 1885-ben alapító tagja Maria Dorothea Egyesületnek, amelynek 1889-től haláláig alelnöke volt. 1911-től a budapesti Állami Nőipariskola igazgatója lett. Számos publikációjában foglalkozott a nőoktatás kérdésével (Loutfi, 2006).

Stetina Ilona tehát saját jogán is szerkesztővé válhatott volna, ugyanakkor érdemes megjegyezni, hogy férjétől, Sebestyén Gyulától (1848-1911) vette át az újság szerkesztését, aki a dualizmus korának neves történésze, pedagógusa és múvelődéspolitikusa volt. Elképzelhető, hogy saját érdemei mellett családi kapcsolata is szerepet játszott a poszt elnyerésében, noha erről biztosat állítani nem lehet. Alakja beleillik abba a trendbe, mely szerint a vizsgált lapokban megjelenő nők többsége a néptanítói elithez tartozott, vagy oda tartott. Stetina Ilonán kívül igazgatónő volt vagy hamarosan az lett Binder Laura, DeGerando Antonina, (Lázárné) Kasztner Janka, Nemessányi Adél és Schwarzel Adél.

Vagyis hiába jelentek meg a nők egyre nagyobb számban a tanítói pályán, a pedagógiai közéletbe való bekapcsolódásra csak azoknak volt reális esélye, akik maguk is valamilyen hatalommal rendelkeztek. Különösen feltúnő ez a Család és Iskola Pedagógiai esetek címú rovatában, amely kifejezetten a néptanítói tapasztalatok gyưjitését tûzte ki célul. A rovatban csupán két tanítónő, Nemessányi Adél és Józsa Dánielné publikált.

Már a női szerzők alacsony számából kiindulva is megfogalmazható a következtetés, hogy a tanítónők megjelenését a szakmában nem követte a szakmai nyilvánosság formáinak hasonló ütemú átalakulása.

\section{A „TANÍTÓNŐI TÉMÁK” HIÁNYA}

A témákat elemezve megállapíthatjuk, hogy a publikáló tanítónők írásaiban megjelenik a nőoktatás (Binder, 1887; Lázárné, 1888) kérdése. Néhány cikk tartalmazott nemzetközi kitekintést, elsősorban külföldi intézmények (The Royal 
Holloway College, Cheltenham Ladies College) nevelési gyakorlatát ismertetve, néhány pedig a külföldi leánynevelés nem intézményes kezdeményezésivel foglalkozott.

A „tipikus” tanítónői cikkekben azonban jellemzően nem jelenik meg valamiféle önálló női hang és témaválasztás, azok témái belesimultak a folyóiratok témái közé. Ez is alátámasztja, a fentebb említett, a témák formálására való képtelenséget.

A tanítónők tanulmányai jellemzően a folyóiratok olyan tipikus témái körül mozognak, mint a módszertan, vagy a család és iskola viszonya. Nemessányi Adél (1889) a magántanítás előnyeiről írt „pedagógiai esetet”, Lázárné Kasztner Janka (1889) pedig Herbert Spencer az erkölcsi nevelésről vallott elveit ismertette.

Módszertani közleményeik a földrajz és természetrajz (Binder, 1888, 1889a, 1889b) a rajz (Körösi, 1888), a matematika (Schwarzel, 1889), és az anyanyelv (Binder, 1890; Czukrász, 1890) tanításával foglalkoztak. Szintén módszertani jellegû volt Pap Mari (1890) cikksorozata az elmézésről.

A tanítónők közül többen (pl. Binder, 1889a, 1889b; Schwarzel, 1887, 1888) éles tollú, igen kritikus recenzensnek bizonyultak. Kritikáikban a témákban láthatóan magabiztosan mozogva rámutatnak a férfi szerzők által írt tankönyvek módszertani és tárgyi tévedéseire.

Ebben az értelemben atipikusnak számítanak azok a cikkek, amelyek kifejezetten a tanítónők helyzetére reflektálnak. Néha csak egy rövid utalást találunk, mint például Burogány Mariska írásában, aki egy, a finn nők helyzetét ismertető amerikai cikket fordított magyarra. Ebben található az alábbi leírás a finn tanítónőkről: „Említésre méltó azonban, hogy ugyanazon munkáért sohsem részesülnek ugyanolyan fizetésben, mint férfi kollégáik. Nem tudom, igaz-e, de hallottam olyan vidéki iskolákról, hol a férfi tanító tehenének eltartására 20 dollárt utalványozott a község évenkint, míg a tanitónö tehenének 15 dollár értékü takarmánnyal kellett beérnie. Ezt megvallom, kegyetlenségnek találom a szegény tehénnel szemben, melynek így kell bünhődnie azért, hogy tulajdonosa a gyengébb nemhez tartozik" (Burogány, 1890. 248. o.). A rövid szövegben a szerző a mai napig jól ismert wage gap jelenségére hívja fel a figyelmet.

Tulajdonképpen ez a jelenség volt az apropója a tanítónők helyzetére legmélyebben reflektáló cikknek, melyet Nemessányi Adél írt. Nemessányi cikke tulajdonképpen válasz Vécsey Jánosnak egy korábbi cikkére, melyet a tanítói fizetések ügyében írt. Ebben számos támogatható elemet lát, mint például a szolgálati hely „drágasági viszonyai” vagy a pályán eltöltött idő szerint differenciált fizetések.

Erősen kifogásolta viszont Vécsey azon álláspontját, mely szerint a tanítónőket a férfiaknál alacsonyabb fizetés illetné. „Hogy hosszadalmas ne legyek, röviden elmondom, hogy Vécsey kartársunk s vele együtt a társaságnak egy bizonyos elfogultan gondolkodó része, a tanitónők számára a férfitanitónak meghatározandó fizetésnél kisebb díjazást kíván megszavazni, azzal érvelvén, hogy: a tanitónő hivatásának teljesitése sokkal könnyebb munkával jár, mind a férfi tanitóé, - a tanitónőt nagy fizetése fényüzővé 
teszi, - nincsen annyi kötelezettsége a társadalommal szemben, mint tanítónak, - ha férjhez megy férjének is van fizetése, - helyettesitése az iskolafentartó községet nagyon megterheli, - végül állítja, hogy a felsö leányiskolánál a kormány a szerinte helyes elvböl indulva ki, máris tesz különbséget a két nemü tanerők között" (Nemessányi, 1890, 281. o.).

Nemessányi hosszasan utasítja el és cáfolja Vécsey elképzeléseit, alaposan körbejárva az ellenérvek minden pontját. Kijelenti, hogy a tanítónők munkája nem könnyebb, nem igényel kevesebb felkészülést, mint a férfitanítóké, legfeljebb irányában különbözik, amennyiben a lányok nevelése különbözik a fiúk nevelésétől. A tanítónők társadalmi kötelezettségeit is hosszasan sorolja, bizonyítva, hogy azok sem kevesebbek a férfitanítók kötelességeinél. Ugyanúgy tagjai különféle helyi és országos szakmai és jótékony egyleteknek, ráadásul tájékozódásukhoz nekik elő kell fizetni azokra a lapokra, amelyeket a férfiak a kaszinókban megkaphatnak. Árnyaltan elemzi a férjezett tanítónők helyzetét is, kiemelve például, hogy a tanítónők férjhezmenetele egyáltalán nem olyan elterjedt, mint azt a férfitársadalom feltételezi. A gyermeket nevelő férjezett tanítónők alkalmazását viszont ellenzi, nem tudnak két szerepben is teljesen megfelelni. A felső leányiskolák tanerőinek fizetése közötti különbséget Vécseyvel ellentétben nem a kormány szándékában látja. Kiemeli, hogy a különbség oka, hogy az ilyen iskolákban a férfitanerők többsége eredetileg középiskolára képesített.

Érvelése olykor nem nélkülözi az ironikus hangnemeit sem. "Ha már most ily fontos teendőkkel jár a tanítónő hivatása, vajjon ráér-e ily körülmények között a mai társadalom egyik nagy hibáját: a fényüzést gyakorolni? Bizony mondom, csak üres lelkü nö s még üresebb lelkü tanitónő lehet az, a ki a divat bábjává törpül s egyéb női és tanítónői magasztos kötelességek helyett csak teste szolgálatába szegödik! A tanítónőnek kell ugyan arra nézni, hogy a társaságban tisztességesen felöltözve megjelenjék, ruhája ne legyen a mult század divata szerint varrva különben nevetségessé s gúny tárgyává válhatik, - mindez azonban nem feltételezi, hogy az illető azután fényt üz s hiábavalóságra költekezik. Ha pedig egyik-másik fiatalabb társunk kelleténél többet gondol a maga külsejével, úgy az bár nem helyeselhetö, de mindenesetre kissé menthetö azzal is, hogy többé kevésbbé minden ember hiú s azért vannak bizony piperkőcz férfitanitók is, a kik féltékenyen ügyelnek arra, hogy ruházatuk minden darabja a legutolsó divat szerinti legyen. Egyébiránt szorosan vizsgálva a dolgot, annak a sokat s méltán kárhoztatott fenyïzésnek is csak a férfiak a közvetett okai. Kiveszi észre mostani világban az olyan leányt, ki szerény, csendes magaviselete mellett egyszerü ruhában jelenik meg valahol, vajjon nem a diszesen kiöltözött, bár sokszor bizony annál üresebb lelkü nők lesznek a férfiak által kitüntetve; a jól nevelt, szerény leány pedig elmélkedhetik a fölött, mennyire különbözik sokszor a szépen hangoztatott theoria a praxistól" (Nemessányi, 1890. 284. o).

A Nemessányi által megütött hangnem és az általa felkarolt témák szokatlanok voltak a korszakban. Ahogy utaltam rá, gyakorlatilag hiányzott az elemzett folyóiratokban a tanítónők egyenlőségéért folytatott harc. A folyóiratokban 
publikáló tanítónők nem a harc stratégiáját, hanem az idomulás, alkalmazkodás stratégiáját választják. Ezen a stratégián keresztül nem csak a diskurzusokba történő, bár meglehetősen korlátozott bekapcsolódásra nyílt lehetőség, hanem —ahogy azt Czukrász Róza példája mutatja —, később akár a néptanítói tudáskánon jelentős mértékú alakítására is.

Már a korszakban sem példa nélküli a női tankönyvszerző. Scwarczel Adél például földrajz tankönyvet írt az elemi népiskola harmadik osztálya számára. De, tudomásunk szerint, Czukrász Róza az egyetlen közülük, aki a férfiakhoz hasonló szimbolikus hatalommal rendelkezett. Számos tankönyv szerzője volt (Czukrász, 1899, 1903, 1934), az általa feltalált, népszerüsített olvasástanítási elvek a 20. század első felében rendkívül elterjedtté váltak.

„Olvasástörténetünk leghatékonyabb módszere a fonomimika volt, Tomcsányiné Czukrász Róza találmánya. A fonomimika - mint neve is mutatja - a hangot és a mozgást kapcsolta össze: a hanghoz egy kézmozdulatot rendelt, a kézmozdulatot mindig jobb kézzel kellett végezni, s az összeolvasáskor is alkalmazták. Az olvasástanításnak tudniillik két kritikus pontja van: a hang-betü kapcsolat kialakítása és rögzítése, valamint az összevonás/kapcsolás vagy összeolvasás. A hanghoz társított kézmozdulat bevitte a cselekedetést a tanításba (mnemotechnikai szerepe is volt), s az együttmozgással segítette az összeolvasást. Tomcsányiné tisztában volt a 20. század eleji reformpedagógia törekvéseivel, tagja volt a Magyar Gyermektanulmányi Társaságnak, ezenkívül igen okos tanitónő volt, elsősorban saját megfigyeléseire és tapasztalatára támaszkodott. Az 1925 és 1950 közötti ábécék fonomimikaiak voltak, a fonomimikát ajánlották a korabeli tantervek is. Rendkívül hatékony módszer volt, tudomásom szerint a tömegoktatásban csak nálunk alkalmazták, magyar találmány, olvasástanításunk jellegzetessége volt. Nyilvánvalóan azért is, mert több érzékszervet mozgatott meg, ezáltal többféle gyerektípusnak volt megfelelo; módszeressége mellett játékos is volt, s ily módon megfelelt a nagyobb mozgásigényü, egyhelyben még nehezen ülő kisgyereknek" (Adamikné, 2006. 81-82. o.).

\section{A TANÍTÓNŐI STRATÉGIÁK ÉRTELMEZÉSE}

A kutatás eredményeképpen tehát megállapítható, hogy a tanítónők részvétele egyedül a Nemzeti Nőnevelésben nevezhető erősnek. A többi folyóiratban országos arányukat jóval alulmúló arányban publikáltak tanítónők. A témaválasztásaik színesek voltak, de alkalmazkodtak a folyóiratok meghatározó témáihoz. Kevés explicit utalást tettek a tanítónők helyzetére, valamint elvétve jelennek meg külföldi példák a publikációikban. Érdekes kérdés, hogy a magyar tanítónők vizsgált írásaiban miért nem jelenik meg erőteljesen a tanítónők helyzetére irányuló reflexió, illetve miért választják az alkalmazkodás stratégiáját.

A vizsgált időszakban a szerkesztői posztokon, a Nemzeti Nőnevelés két évfolyamát kivéve csak férfiakat találunk. Az általuk birtokolt valós hatalom erôsen korlátozhatta a nők részvételi lehetőségeit a szimbolikus hatalom birtoklásában, 
vagyis a részvétel lehetőségét a néptanítói tudáskánon alakításában, és az arról folyó diskurzus formálásában.

Az alkalmazott stratégiával kapcsolatban érdemes utalni Mineke van Essen kutatására, aki a holland tanítónők mozgalmait vizsgálva azok három stratégiáját azonosította: a professzionalizáció, a hagyományos női területek védelme és kiterjesztése, valamint a harc az egyenlőségért (v. Essen, 1999).

A magyar tanítónők esetében a vizsgált forrásbázison egyik stratégia sem azonosítható. Van Essen a professzionalizáción a képzési lehetőségek egyenlőségét és az extra képzési lehetőségek keresését érti. Magyarországon a tanítónők képzése azonban, néhány apróbb különbségtől eltekintve, jogilag egyenlő volt a tanítók képzésével. A hagyományos női területek védelmén a nőnevelés női dominanciájának megőrzését érti. Hazánkban azonban, noha a nők jelentôs szerepet játszottak a nőnevelő intézetek kiépítésében, a nőoktatás nem volt egyértelmúen női terület. A korábbi és a jelen kutatás eredményei pedig azt valószínúsítik, hogy a magyar tanítónőkre az aktív harc az egyenlőségért nem volt jellemző.

Van Essen a holland helyzettel kapcsolatban is felveti, hogy az általa azonosított stratégiák nem feltétlenül voltak széles körben használt közösségi cselekvésformák. „Sok különböző tényező járulhatott hozzá ahhoz az alacsony szinthez, amit a feminizáció Hollandiában elért. A női pedagógusok által használt stratégiák ezek egyike lehetett. Ha stratégiáikat azokhoz hasonlítjuk, amelyeket náluk sikeresebb kollégáik alkalmaztak más nyugat-európai országokban, különösen Németországban és Nagy Brittaniában, amelyek szintén protestáns többségüek voltak, egy fontos különbség megfigyelhetö: a holland pedagógusnők - a szakképzésben oktatók kivételével - nem szervezték magukat szándékosan nemi alapon. (...) Emellett nem alakítottak ki erös informális nyomásgyakorló csoportokat karrierlehetőségeik javítása, illetve a lányok oktatásában való monopóliumának védelme és bövitése érdekében. Ehelyett a holland pedagógusnők inkább a férfiakkal való együttmüködést preferálták, és a különbség helyett az egyenlöséget hangsúlyozták. (...) Néhány, az egyenlö keresetre és a házassági tilalom bevezetése elleni tiltakozásra irányuló esetleges csoportos akciók kivételével a cikkben ismertetett tevékenység egyéni kezdeményezés volt" (v. Essen, 1999. 433. o.).

Az általam vizsgált írások szerzői az alkalmazkodás stratégiáját választották, amiről feltételezhetjük, hogy elsősorban a jelentős hatalmi különbségek realitásának tudomásul vételét jelenthette. Hipotézisként megfogalmazgató, hogy a magyar tanítónők reális stratégiája éppen ezért nem a férfitanítókkal párhuzamos közösség kiépítése, hanem a férfiközösségen belül történő érvényesülés lehetett. Ez magyarázhatja a nemzetközi példák hiányát is, hiszen nem elsôsorban a külföldi mintákhoz való alkalmazkodás lehetett elérendő céljuk.

A kutatás későbbi kiterjesztésének lehetősége a hatalommal kapcsolatos álláspontok áttekintése. Farkas Zoltán (2001) tanulmányában a hatalom fogalma értelmezésinek sokszínúségére hívja fel a figyelmet, és kísérletet tesz saját hatalomfogalmának kidolgozására, melyben különbséget tesz a társadalmi erő, a hatalom és az uralom fogalma között. Ezek részletes ismertetése a jelenlegi 
kutatás kereteit szétfeszítené, így csak arra utalunk, hogy értelmezésében „A hatalom az adott egyén (vagy csoport) nagymértékú társadalmi erejéböl és a nagymértékben egyenlötlen társadalmi eröviszonyokból eredö társadalmi eröfölénye a társadalmi élet adott területén, az egyének (vagy csoportok) adott körében. E szerint hatalmi viszonyoknak nevezzük az olyan nagymértékben egyenlötlen társadalmi eröviszonyokat, amelyekben egy adott egyén (vagy csoport) hatalommal rendelkezik a másik egyénnel (vagy csoporttal), illetve más egyénekkel (vagy csoportokkal) szemben. (...) A hatalom az adott egyénnek (vagy csoportnak) aktuálisan lehetöséget nyújt mások érdekei érvényesülésének alapvetöen egyoldalú befolyásolására, és ezáltal saját érdekei, illetve az általa képviselt érdekek kiemelkedő mértékú érvényesitésére" (Farkas, 2011. 36-39. o.).

Mivel láthattuk, hogy a valódi hatalom (pl. igazgatói posztok) birtokosai, ha még csekély számban is, de lehettek nők, olyan elméletek segíthetik a feltárt jelenségek elemzését és értelmezését, amelyek expliciten reflektálnak a valódi és a szimbolikus hatalom (tőke) közötti különbségekre.

Ezért a további kutatások kiindulópontja lehet Bourdieu tőkeelmélete. Ő így fogalmaz a szimbolikus tőkével kapcsolatban: „A hatalmat elsősorban a gazdasági tőke (és annak különböző formái), a kulturális tőke és a társadalmi töke, valamint a szimbolikus tőke jelenti. A szimbolikus tőke, amit általában presztízsnek, hírnérnek stb. neveznek, nem más, mint a többi tökefajta legitimként észlelt és elismert formája. [...] A közös értelmezés kialakitása körül folyó vagy, pontosabban szólva, a legitim megnevezés monopóliumáért - vagyis a társadalmi világ legitim szemléletmódjának hivatalos (tehát explicit és nyilvános) elfogadtatásáért - vívott szimbolikus harcban a cselekvök azt a szimbolikus tökét használják fel, amelyre a korábbi harcok során tettek szert, és különösen mindazt a hatalmat, amellyel az intézményesült - a hivatalos minősitésekhez hasonlóan a gondolkodásban rögzült vagy tárgyiasult - taxonómiák felett rendelkeznek. Így mindazok a szimbolikus stratégiák, amelyek segitségével a cselekvők megpróbálják másokkal elfogadtatni a társadalmi világ felosztásáról és a benne elfoglalt pozíciójukról kialakitott szemléletmódjukat, két végpont között helyezkednek el: az egyik a sértés, egy idiosz logosz, amely által az egyén igyekszik saját látásmódját másra rákényszeríteni, ugyanakkor joggal tarthat attól, hogy a másik fél is ugyanerre törekszik; a másik végpont a hivatalos megnevezés, vagyis a szimbolikus kikényszerítés aktusa, amely mögött ott áll a közösség, a konszenzus és a közös értelmezés minden ereje, hiszen ezt az aktust a legitim szimbolikus erőszak monopóliumával rendelkező állam megbizott képviselöje végzi el" (Bourdieu, 2013. 167-171. o.).

Bourdieu elmélete jól magyarázhatja, hogy a hatalom birtokában lévő férfi pedagógusok miért voltak képesek az igazodás stratégiájára kényszeríteni a nyilvános pedagógiai térbe belépő tanítónőket.

\section{ÖsSZEGZÉs}

Tanulmányunkban a néptanítói szakma feminizációjának dualizmus-kori történetét vizsgáltuk, a dualizmus-kori pedagógiai szaksajtó segítségével. Azt vizsgáltuk, hogy a pálya feminizációja megnyitotta-e az utat a tanítónők szá- 
mára a folyóiratokban folyó szakmai diskurzusokban történő megjelenésre. A vizsgált forrásainkból kiderül, hogy a tanítónők számarányuknál kisebb súllyal tudtak részt venni a pedagógiai közéletben és nem tudták vagy akarták saját hangjukkal érdemben befolyásolni a szakmai diskurzusokat.

Véleményünk szerint a kutatás folytatásának egyik lehetőségét a hatalom értelmezésének vizsgálata jelentheti, amely választ adhat arra a jelenségre, hogy miért nem tudták a tanítónők a rendszerben lévő súlyukat hatalomra konvertálni. A hatalom kérése mellett szintén kutatásra érdemes kérdés a századvégen megerősödő hazai feminista mozgalmak és a tanítónői egyesületek, mozgalmak jelenleg még csak részben feltárt kapcsolata (Kereszty, 2011a). A vizsgált időszak kiterjesztése a századforduló utáni és a két világháború közötti évekre szintén tovább árnyalhatná a most felvázolt képet.

\section{IRODALOM}

Adamikné Jászó Anna (2006): Az olvasás múltja és jelene. Az olvasás grammatikai, pragmatikai és retorikai megközelítésben. Trezor Kiadó, Budapest.

Albisetti, J. C. (1993): The feminization of teaching in the nineteenth century: a comparative perspective. History of Education, 22. 3. sz. 253-263. doi: 10.1080/0046760930220305

Binder Laura (1887): A berlini nők kérvénye a nőnevelés érdekében. Család és Iskola, 13. 178-183.

Binder Laura (1888): Humboldt elve a természetrajz tanításánál. Család és Iskola, 14. 124. és 130-131.

Binder Laura (1889a): Földrajz a polg. 1. iskolák I. osztálya számára. Írták: dr. Hunfalvy J. és Schneider János. Család és Iskola, 15. 47., 55. és 63.

Binder Laura (1889b): Szemléltető eszközök a hazai földrajz tanításához. Család és Iskola, 15. 67-69.

Binder Laura (1890): Helyesírás és fogalmazás. Család és Iskola, 16. 56-57., 67-68. és 77-78.

Biró Zsuzsanna Hanna (2014): A németszakos diploma szerepe a nők érvényesülésében 1895 és 1945 között. In: Fizel Natasa és Nóbik Attila (szerk): Ünnepi tanulmányok Pukánszky Béla tiszteletére. Szegedi Egyetemi Kiadó, Juhász Gyula Felsőoktatási Kiadó, Szeged. 11-34.

Bourdieu, P. (2013 [1985]): A társadalmi tér és a csoportok keletkezése. In: Angelusz Róbert, Gecser Ottó és Éber Márk Áron (szerk.): Társadalmi rétegződés olvasókönyv. (E-book.). ELTE, Budapest. 164-177.

Online:http:/ /www.tankonyvtar.hu/hu/tartalom/tamop425/0010_2A_19_Tarsadalmi_retegzc 2018.03.06.

Burogány Piroska (1890): A nők helyzete Finnországban. Nemzeti Nőnevelés, 11(4), pp. 237-243.

Clifford, G. J. (2014). Those Good Gertrudes: A social history of women teachers in America. Baltimore: Johns Hopkins University Press. 
Cortina, R. és San Román, S. (2006, szerk): Women and Teaching. Global Perspectives on the Feminization of a Profession. Palgrave McMillan, New York.

Czukrász Rózsa (1890): Szépírás-minták a népiskolában. Család és Iskola, 16. 89-90.

Czukrász Rózsa, Tomcsányiné (1899): Phonomimikai elogyakorlatok az olvasás és írás tanításához. Nagel, Budapest.

Czukrász Rózsa, Tomcsányiné (1903). A magyar gyermek első könyve. Lampel, Budapest.

Czukrász Rózsa, Tomcsányiné (1934). A fonomimikai módszer Magyarországon. Lampel, Budapest.

De Gabriel, N. (2014). The entrance of women into the teaching profession in Spain (1855-1940). History of Education. 43. 3. sz. 334-354. doi: 10.1080/0046760x.2014.896050

Farkas Zoltán (2011): A hatalom és az uralom fogalma. Politikatudományi Szemle 20. 2. sz 31-49.

Fizel Natasa (2018): A magyar polgári iskolai tanárképzés története (1868-1947). Esély az együttmüködésre - Professzionalizáció és intézményesülés. Gondolat Kiadó, Budapest.

Fónai Mihály és Dusa Ágnes Réka (2014): A tanárok presztízsének és társadalmi státuszának változásai a kilencvenes és a kétezres években. Iskolakultúra. 24. 6. sz. 41-49.

Guildford, J. (1992). „Separate Spheres”: The Feminization of Public School Teaching in Nova Scotia, 1838-1880, Acadiensis. 22. 1. sz. 44-64.

Hegedûs Judit (2003): Tanítónői karriertörténetek a dualizmus korában. Iskolakultúra, 23. 3. sz. 42-52.

Kékes Szabó Mihály (2003): A tanítóképzés kritikus pontjai a dualizmus időszakában. Iskolakultúra, 13. 3. sz. 17-24.

Kelleher, F. (2011). Women and the Teaching Profession. Exploring the Feminisation Debate. Commonwealth Secretariat, Unesco, London, Paris.

Kereszty Orsolya (2011a): „A Nós és a Társadalom” a nők müvelódéséért (1907-1913). Magyar Tudománytörténeti Intézet, Budapest.

Kereszty Orsolya (2011b): A munkavállalás rekonstruált diskurzusai a feminista mozgalom hivatalos folyóiratában. Magiszter, 9. 3. sz. 86-97.

Kéri Katalin (2008): Hölgyek napernyővel. Nők a dualizmus kori Magyarországon. 1867-1914. Pro Pannonia, Pécs.

Komáromy Lajos (1890): Népoktatásunk állapota 1888-89-ben. II. Nemzeti Nőnevelés, 18. sz. n. 75-78.

Kovács Edina (2015): A pedagógushallgatók pályaképének és eredményességének jellemzői a Magyarország - Románia - Ukrajna határmenti régióban. In: Kozma Tamás, Kiss Virág Ágnes, Jancsák Csaba és Kéri Katalin (szerk): Tanárképzés és oktatáskutatás. Magyar Nevelés- és Oktatáskutatók Egyesülete (HERA), Debrecen. 445-456. 
Körösi Marcsa (1888): Rajz a női kézimunkák szolgálatában. Család és Iskola, 14. 54 .

Lázárné Kasztner Janka (1888) Továbbképző iskolák leányok számára. 1888. Család és Iskola, 14. 64-66.

Lázárné Kasztner Janka (1889): Spencer Herbert elvei az erkölcsi nevelésről. Család és Iskola, 15. 6-7., 15-16. és 23-24.

Lázárné Kasztner Janka (1890): Megtíltandó-e gyermekeknek, hogy az iskolában történtekről ne beszéljenek. Család és Iskola, 16. 98-99.

Loutfi, A. (2006): Stetina, Ilona (Mrs Gyula Sebestyén) (1855-1932). In. Francisca de Haan, Krassimira Daskalova, Anna Loutfi (szerk): A Biographical Dictionary of Women's Movements and Feminisms. Central, Eastern, and South Eastern Europe, 19th and 20th Centuries. Central European University Press, Budapest. 539-543.

N. Tóth Ágnes (2014): Mérföldkövek a pedagógussá válás folyamatában empirikus kutatás a Nyugat-magyarországi Egyetemen végzett pedagógusok körében. Magyar Pedagógia, 114. 1. sz. 25-48.

Nagy Mária (2001): A tanítóság a századelőn, a statisztikai adatok tükrében. In: Baska Gabriella, Nagy Mária és Szabolcs Éva (szerk.): Magyar tanító, 1901. Iskolakultúra Könyvek, Pécs. 11-37.

Nagy Mária (2006): Magyar tanító, 1911-ben. Iskolakultúra, 16. 2. sz. 33-48.

Nemessányi Adél (1889): A magántanítás előnye. Család és Iskola, 15. 72-173.

Nemessányi, Adél (1890): Néhány szó a tanítónő munkájáról s díjazásáról. Felső Nép-és Polgári Iskolai Közlöny, sz. n. 278-289.

Neszt Judit (2010). A tanítói pálya elnőiesedésének történeti előzményei. Educatio, 19. 2. sz. 315-321.

Nóbik Attila (2014): A dualizmus-kori pedagógiai közélet jellemzői a Család és Iskola példáján. In: Fizel Natasa és Nóbik Attila (szerk.): Ünnepi tanulmányok a 60 éves Pukánszky Béla tiszteletére.

Pap Mari (1890): A szóról szóra való emléztetés módjának, tárgyainak és értékének meghatározása a népiskolában. Család és Iskola, 16. 163-164., 171-172., 183. és 191-192.

Pukánszky Béla (2006): A nőnevelés évezredei. Gondolat Kiadó, Budapest.

Sager, E. W. (2007). Women Teachers in Canada, 1881-1901: Revisiting the 'Feminization' of an Occupation. The Canadian Historical Review, 88. 2. sz. 201-236.

Schwarzel Adél (1887): Györffy-féle népiskolai képes tankönyvek. Család és Iskola 13. 47-48.

Schwarzel Adél (1888): Kis földleírás. Írta Ribáry Ferencz. Család és Iskola 13. 186-187.

Schwarzel Adél (1889): A felsőbb osztályokban szükséges-e a szemléltetés a számtani múveletek tanításánál, s ha igen, milyen legyen az? Család és Iskola 15. 50-51. 
Strober, M. H. és Lanford, A. G. (1986): The Feminization of Public School Teaching. Cross-Sectional Analysis, 1850-1880. Signs: Journal of Women in Culture and Society, 11. 2. sz. 212-235. doi:10.1086/494217

Sztrinkóné Nagy. Irén (2005). A női szerep változásai és a reformpedagógia. Iskolakultúra, 25. 2. sz. 63-68.

Thun Éva (2012): A magyarországi nőnevelés-történet fő kérdései feministaés pedagógiai historiográfiai szempontból vizsgálva. In. Garaczi Imre (szerk): Érték és sors: nemzetpolitika, kulturális örökség, identitás. Veszprémi Humán Tudományokért Alapítvány, Veszprém. 353-370.

Tóth Tamás (2001): A napóleoni egyetemtől a humboldti egyetemig. In: Tóth Tamás (szerk.): Az európai egyetem funkcióváltozásai. Professzorok Háza, Budapest. 95-123.

Trouvé-Finding, S. (2005). Teaching as a woman's job: the impact of the admission of women to elementary teaching in England and France in the late nineteenth and early twentieth centuries. History of Education, 34. 5. sz. 483-496. doi: 10.1080/00467600500220689

v. Essen, M. (1999): Strategies of women teachers 1860-1920: feminization in Dutch elementary and secondary schools from a comparative perspective. History of Education, 28. 4. 413-433. 